\title{
The chemical composition and shape of inclusion of amethyst
}

\author{
Si-Nae Yoon, Young Jun Song*,† and Seog-Joo Yon** \\ Department of Gemology, Daegu Polytechnic College, Daegu 706-711, Korea \\ *Department of Materials and Metallurgical Engineering, Kangwon Univ., Kangwon 245-711, Korea \\ **Department of Gemological Engineering, Dongshin University, Naju 520-714, Korea
}

(Received September 27, 2010)

(Revised October 4, 2010)

(Accepted October 12, 2010)

Abstract This study was carried out for the purpose of obtaining the basic data for identifying the origin of amethyst. For this, the three dimensional shapes of inclusions contained in various amethyst were observed with Stereo Zoom microscope. The shape and chemical composition of cross section of solid inclusion and the chemical composition of evaporite were investigated by SEM-EDS. The evaporite is made from evaporating of liquid inclusion which is flowed out of amethyst sample by decompressing. Lastly, The trace mineral composition of amethyst was investigated by ICP-AES after digesting the amethyst sample with $\mathrm{HF}-\mathrm{H}_{2} \mathrm{SO}_{4}$ solution.

Key words Identification, Origin of amethyst, Chemical composition, Inclusion, SEM-EDS

\section{자수정 내포물의 형상과 화학조성에 관한 연구}

\author{
윤시내, 송영준 $* \dagger$, 연석주** \\ 대구산업정보대학 보석감정과, 대구, 706-711 \\ *강원대학교 재료금속공학과, 강원, 245-711 \\ **동신대학교 보석귀금속과, 나주, 520-714 \\ (2010년 9월 27일 접수) \\ (2010년 10월 4일 심사완료) \\ (2010년 10월 12일 게재확정)
}

요 약 본 연구는 자수정의 산지에 따른 내포물의 성상 변화를 조사함으로써 자수정의 산지 감별을 위한 기초자료를 얻을 목적으로 수행되었다. 자수정에 포획되어 있는 내포물의 삼차원적 형상을 입체현미경으로 관찰하여 그 특징을 조사하 였고, 각 내포물 중 고체내포물 단면의 형상및 화학조성을 $\mathrm{SEM/EDS로} \mathrm{조사하였으며,} \mathrm{SEM/EDS} \mathrm{관찰을} \mathrm{위한} \mathrm{감압코팅과정}$ 에서 액상포유물의 파괴와 증발에 의해 생성되는 수지상 무늬의 형상과 화학조성을 분석함으로써 액상포유물의 조성도 조 사하였다. 아울러 각 자수정 시료를 플루오르화수소산으로 처리하여 완전 용해시킨 다음 ICP-AES를 이용하여 각종 자수정 에 함유되어 있는 미량 성분의 농도를 정밀하게 분석하여 고찰하였다.

\section{1. 서 론}

자수정에 포획되어 있는 내포물 들은 자수정의 생성환 경과 산지에 관한 다양한 정보를 포함하고 있으며 이를 잘 활용할 경우 자수정의 산지 감별에 매우 유용한 수단 이 될 수 있다.

자수정의 내포물로는 Color banding(색대), Color zoning (색의 농담), 네거티브 크리스털(negative crystal), 침상

\footnotetext{
Corresponding author

Tel: $+82-33-570-6416$

Fax: +82-33-573-6409

E-mail: yjsong64@kangwon.ac.kr
}

고체 내포물, 유체포유물 등이 알려져 있으며, 유체포유 물은 상의 종류 및 충진도 등에 따라 Type I(액상이 내 포물 체적의 $50 \%$ 이상을 차지하며 낮은 염도), Type II (기상이 내포물 체적의 $50 \%$ 이상을 차지하며 낮은 염 도), Type III(액상이 풍부하며 암염-halite, $\mathrm{NaCl}$-을 자 광물-Daughter mineral-로 가지는 염도가 매우 높은 집 단), Type $\operatorname{IV}\left(\mathrm{CO}_{2}\right.$ 를 함유하며 염도가 낮은 수용액과 액 체 $\mathrm{CO}_{2}$ 와 기체 $\mathrm{CO}_{2}$ 를 함유한 집단)로 분류된다.

Color banding의 경우, 자주색과 보라색 또는 무색의 평행한 색대(色帶)나 각이 진 색대가 능면체의 면에 평 행하게 두세 방향으로 나타나면 이는 천연 자수정의 특 징이 된다는 주장이 있다[1]. 
Color zoning의 경우, 천연은 무색에서 보라색으로 자 연스럽게 육모꼴의 성장패턴에 색상이 나타나는 반면 합 성은 무색인 부분이 없으며 옅은 보라색에서 짙은 보라 색을 나타낸다 [2]. Color zoning은 주로 천연자수정에 서만 나타나지만 드물게 합성 자수정에서도 나타날 수 있다. 러시아에서 생산된 합성 자수정 중에 'speckled' 또는 'leopard spot' 등의 특이한 형태를 나타내는 Color zoning이 있다는 보고가 있다[3].

유체포유물은 자수정 생성 당시의 열수성분인 기체 $\mathrm{CO}_{2}$, 액체 $\mathrm{CO}_{2}$, 소금 결정, $\mathrm{CH}_{4}$, 암염(halite)이나 칼륨암 염(potassic halite)등의 다양한 성분으로 이루어져 있으며 압력이나 온도를 변화시키면 그 상이 변하는 특징을 가 지고 있어 자수정의 산지 뿐만 아니라 그 생성환경을 추 리할 수 있는 가장 유력한 수단 중의 하나가 되고 있다 [4]. 자수정 내에 포획되어 있는 고체 내포물로는 적철석, 칼륨장석 $\left(\mathrm{KAlSi}_{3} \mathrm{O}_{8}\right)$ 결정 등이 알려져 있으며 침상 고체 포유물은 $\mathrm{Fe}$ 가 주 구성 원소라는 연구결과가 있다 $[5,6]$.

이와 같이 자수정에 포획되어 있는 내포물 들은 자수 정의 생성환경과 산지에 관한 다양한 정보를 함유하고 있으며 이를 잘 활용할 경우 자수정의 산지 감별에 매우 유용한 수단이 될 것으로 생각된다.

본 연구에서는 자수정 내포물의 산지별 특성을 조사할 목적으로, 자수정에 포획되어 있는 내포물의 삼차원적 형상을 입체현미경으로 관찰하여 그 특징을 조사하였고, 각 내포물 중 고체내포물 단면의 형상 및 화학조성을 $\mathrm{SEM} / \mathrm{EDS}$ 로 조사하였으며, SEM/EDS 관찰을 위한 감 압코팅과정에서 액상포유물의 파괴와 증발에 의해 생성 되는 수지상 무늬의 형상과 화학조성을 분석함으로써 액 상포유물의 조성도 조사하였다. 아울러 각 자수정 시료 를 플루오르수소산으로 처리하여 완전 용해시킨 다음 ICP-AES를 이용하여 각종 자수정에 함유되어 있는 미 량 성분의 농도를 정밀하게 분석하여 고찰하였다.

\section{2. 실험방법}

\section{1. 시료}

본 연구를 위하여 사용된 시료는 천연자수정과 합성자 수정이며 천연자수정은 국내에서 원석을 수집할 수 있는 8 개국의 것을 사용하였다. 외국산 천연자수정 및 합성자 수정 원석은 보석 유통업체인 Manoel Bernards를 통하여 수집하였으며, 국내산 시료는 국내 대표적인 자수정 광산 인 울진, 동골, 언양의 현지 광산에서 직접 채취하였다.

수집된 8개국의 원석 시료들은 먼저 육안 감별로 대표 성을 띄는 부분을 선정하여 적당한 크기로 cutting하고 두 께를 $1 \mathrm{~mm}$ 로 조정한 다음 양면을 연마하여 사용하였다.

\section{2. 실험방법}

\subsection{1. 현미경 관찰}

현미경을 이용하여 내포물과 미세구조를 관찰하였으며 사용된 현미경은 보석감별용 저배율 현미경인 Leica $48 \times$ Stereo Zoom과 고배율 광학현미경인 Nikon OptiphotPol(UFX-DX)이다.

\subsection{2. 내포물의 성분 검사}

산지별 또는 천연 및 합성자수정의 내포물 성분을 검 사하기 위하여 먼저 편광현미경을 이용하여 내포물을 관 찰하고 분석위치를 결정한 다음 주사전자현미경-에너지 분산 X-선분석기(SEM/EDS:J SM-6300, JEOL, Japan/ ISIS -300, Oxford, England)를 사용하여 그 조성을 분 석하였다. 이때 시료에 도전성을 부여함으로써 이차전자 발생량을 양호하게 하여 이미지 분해능을 향상시킴과 동 시에 $\mathrm{EDS}$ 분석의 정확도를 높일 목적으로 carbon coating을 하였다. 편광 현미경 검사를 위해서는 자수정 원석을 호마이카로 고정시킨 후 $1 \mathrm{~mm}$ 두께로 절단하고 $0.03 \mathrm{Al}_{2} \mathrm{O}_{3}$ 파우더를 이용해 표면을 연마하였다.

\subsection{3. 성분 검사}

자수정의 성분조사를 위하여 $\mathrm{X}$-선 형광분석기(XRF: $\mathrm{Rh}$ target ZSX100e, Rigaku, Japan)를 이용하였으며, 미 량인 원소 함량을 조사하기 위해 유도결합 플라즈마 원 자방출분광기(ICP-AES:Vista-Pro, Varian, Australia)를 이용하였다. XRF 분석을 위하여 마노유발을 이용하여 분쇄한 후 auto press에서 20 ton으로 $\varnothing 30 \mathrm{~mm}$ pellet을 만들어 분석에 사용하였다.

ICP-AES 분석은 분쇄된 시료를 극초단파 시료분해장 치(MDS: FTHOS, Milestone, Italy)를 사용하여 분해하 여 분석하였다. $75 \mu \mathrm{m}$ 이하 크기로 분쇄된 시료 약 50 $\mathrm{mg}$ 을 취하여 그 무게를 정확히 달아 기록한 다음 $\mathrm{MDS}$ 의 테프론제 용기에 넣고 $65 \% \mathrm{HNO}_{3}(5 \mathrm{~m} l), 30 \% \mathrm{H}_{2} \mathrm{O}_{2}$ $(2 \mathrm{ml}), 40 \% \mathrm{HF}(5 \mathrm{~m} l)$ 등과 함께 2시간 동안 분해시킨다. 분해가 끝난 시료용액을 증발건고하여 잔류하는 $\mathrm{HF}$ 를 휘발 제거한 다음 시료를 재차 $65 \% \mathrm{HNO}_{3} 2 \mathrm{~m} /$ 와 증 류수 $20 \mathrm{~m}$ 로 완전히 용해시키고 $100 \mathrm{ml}$ 메스플라스크 로 옮겨 액량이 $100 \mathrm{~m}$ 가 되도록 증류수를 가하여 분석 용 용액으로 하였다.

\section{3. 실험결과 및 고찰}

\section{1. 내포물의 형상}

입체 현미경과 광학현미경을 이용하여 자수정의 내포 


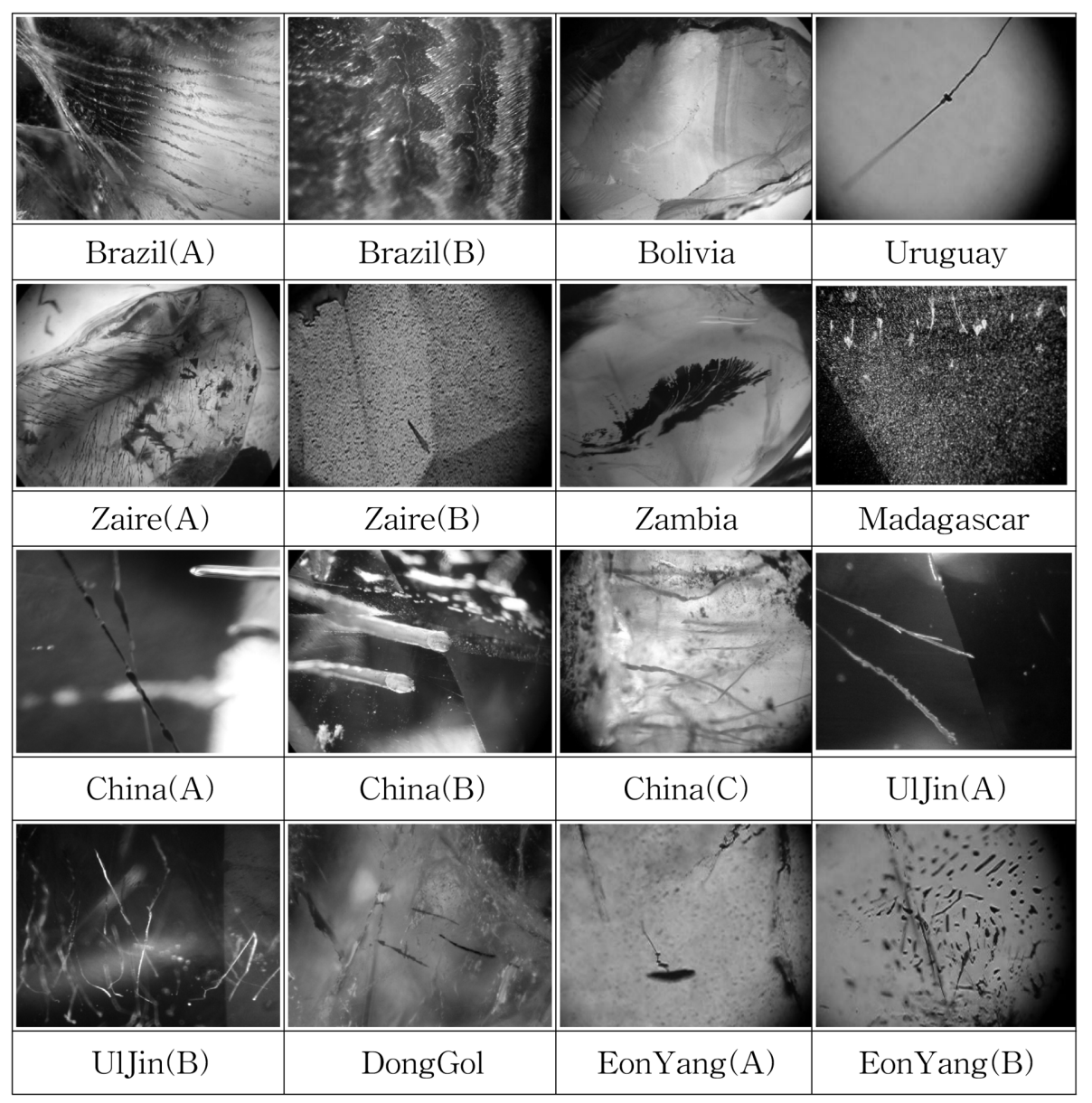

Fig. 1. Photographs of inclusion in amethyst of various origin.

물의 형상을 조사 하였으며 그 관찰 결과를 Fig. 1에 나 타내었다.

그림에서 브라질 자수정에서는 직선상으로 배열되어 있는 유체포유물 들이 다수 관찰되며(Brazil(A)), 접촉쌍 정의 일종인 Brazil Law twins을 갖는 결정의 단면에서 관찰되는 얼룩무늬인 'Zebra-striation' 또는 'Tiger stripes' (Brazil(B))도 관찰되는 특징이 있음을 알 수 있다.

남미 대륙의 볼리비아 자수정에서는 자주색이 뭉쳐서 나타나는 색대가 관찰되며, 우루과이 자수정에서는 마디를 갖는 가늘고 긴 침상 집합체들이 특징적으로 관찰된다.

아프리카 대륙의 자이레 자수정에서는 수정의 성장면에 평행하게 배열된 붉은 침상 내포물이 관찰되고(Zaire(A)), c축의 직각 방향으로 절단된 시편에서는 쌍정이 관찰되며 쌍정각은 $40 \sim 45^{\circ}$ 범위를 갖는 특징을 보였다(Zaire(B)). 잠비아 자수정에서는 침상 내포물들이 새의 날개 모양으 로 배향하는 특징을 보였으며, 마다가스카르 자수정에서 는 날카로운 화살끝 모양을 갖는 침상의 내포물들이 평 행하게 배열되어 있는 특징과 함께 굵은 침상의 독립 내 포물 들도 관찰된다.

중국 자수정에서는 대나무 마디 모양의 붉은색 침상
내포물(China A)과 관상 산호초 모양의 백색 내포물 (China B), 그리고 가는 해초모양의 섬유상 내포물 (China $\mathrm{C}$ )들이 관찰되는 특징을 보였다. 울진 자수정에 서는 풍뎅이 다리 모양의 붉은 침상 내포물(UlJin(A))과 일정한 배향성이 없는 풀줄기 모양의 적색 내포물 $(\mathrm{UlJin}(\mathrm{B}))$ 들이 관찰되고, 동골 자수정에서는 주로 붉은 색의 굵은 침상 내포물과 함께 약간의 사각형 황색 결정 들도 관찰되는 특징을 보였다. 언양산 자수정에서는 해 파리 모양의 붉은색 고체포유물(EonYang(A))과 평행하 게 배열된 유체포유물군(EonYang(B)) 들이 관찰되는 특 징을 보였다. 이와 같이 자수정의 산지에 따라 내포물의 형상이 달라지는 것은 각각의 자수정들이 고유의 정출환 경을 가지기 때문이며 따라서 보다 많은 내포물에 관한 자료가 축적될 경우 내포물의 형상만으로도 자수정의 산 지를 추정하는 것이 가능할 것으로 생각된다.

\section{2. 내포물의 성분과 단면의 모양}

전술한 내포물 형상 조사에서 관찰된 내포물들의 화학 조성을 알기 위하여 주사전자현미경을 이용하여 $\times 5,000$ 

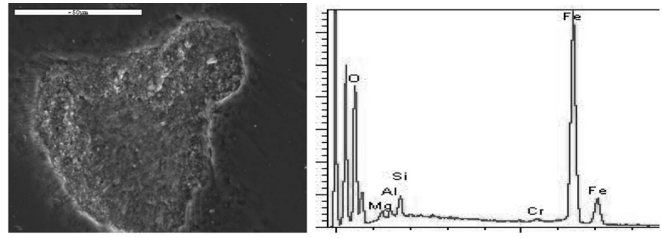

Brazil a (cross section)
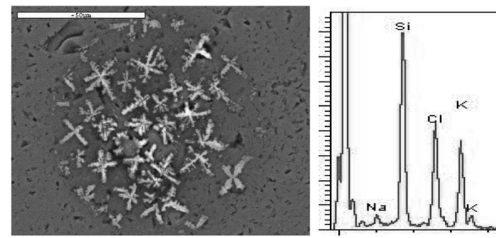

Brazil c(evaporite)

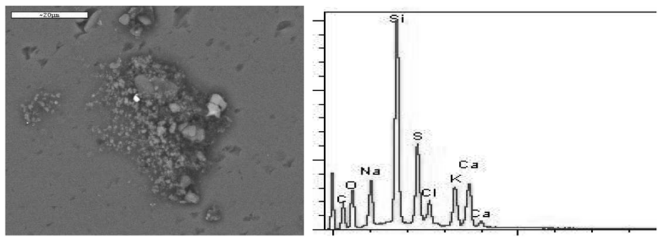

Bolivia b(evaporite)
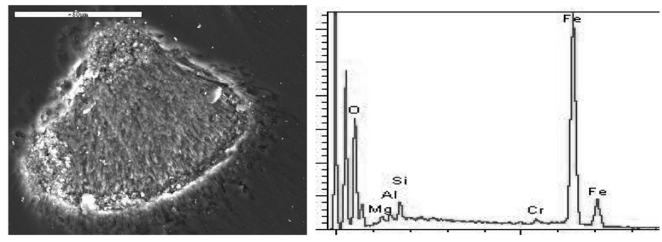

Uruguay a(cross section)

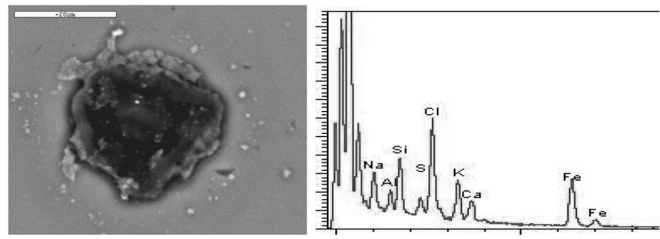

Uruguay c(evaporite)

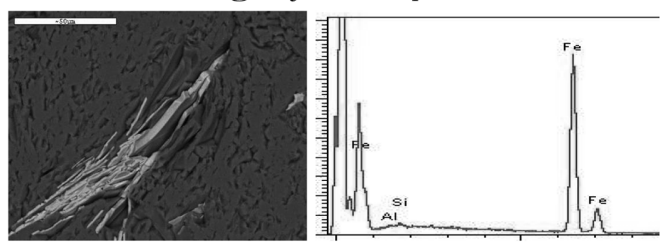

Zaire b(cross section)
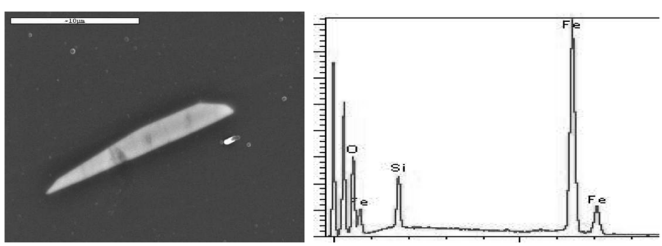

Zambia a (cross section)

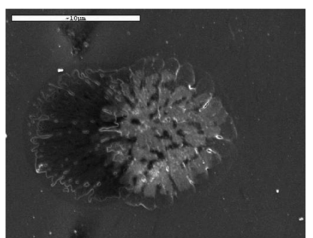

Zambia

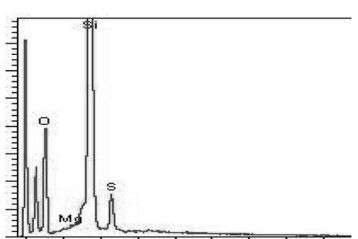

c(evaporite)

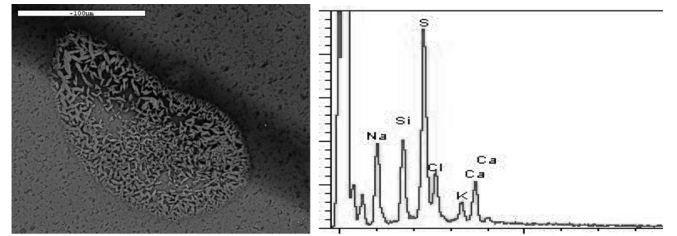

Brazil b(evaporite)

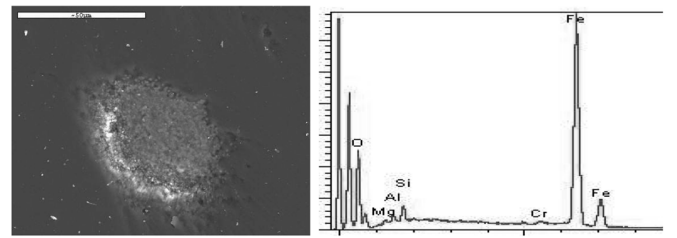

Bolivia a(cross section)

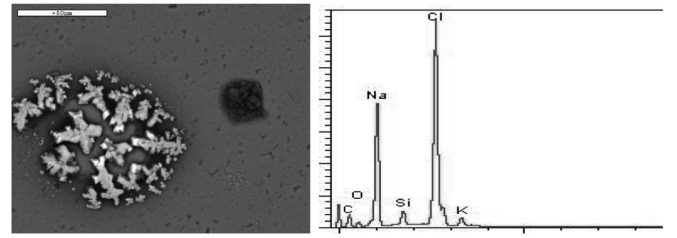

Bolivia c(evaporite)

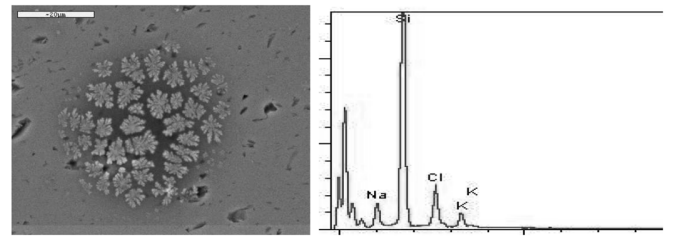

Uruguay b(evaporite)

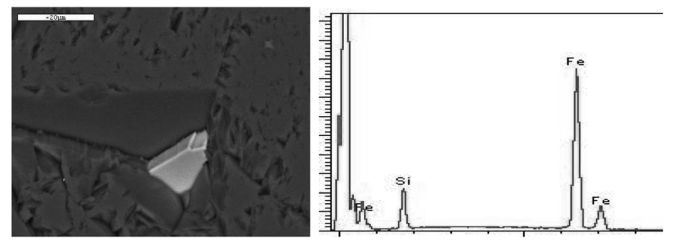

Zaire a(cross section)

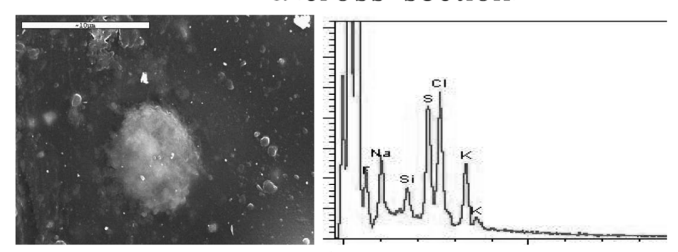

Zaire c(evaporite)

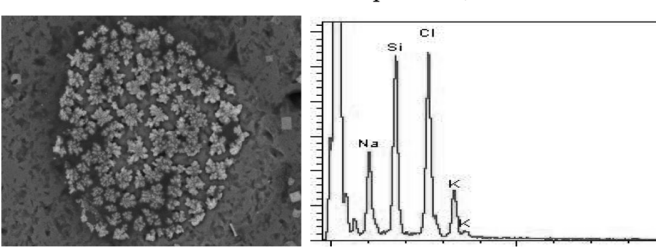

Zambia b(evaporite)
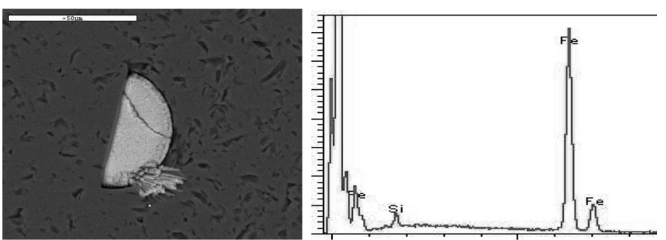

Madagascar a(cross section)

Fig. 2. SEM image and it's chemical composition of cross section of solid inclusion and evaporite of fluid inclusion of amethyst. 

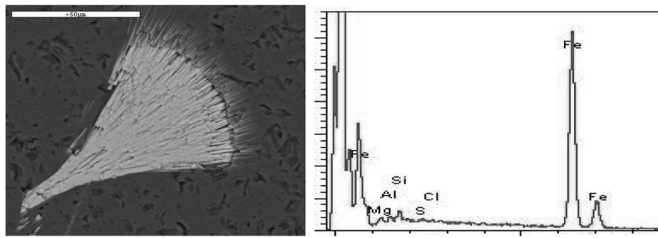

Madagascar

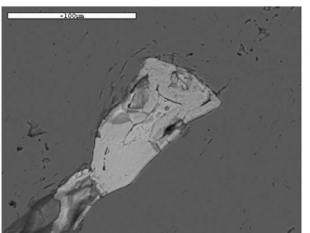

$b$ (cross section)

U1Jin a(cross section)
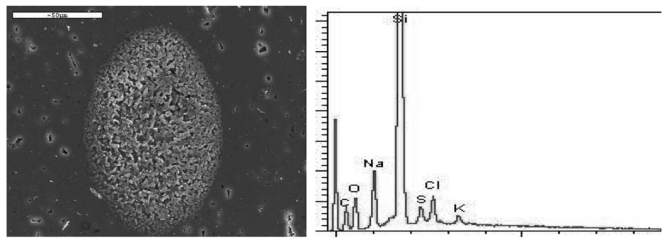

UlJin c(evaporite)
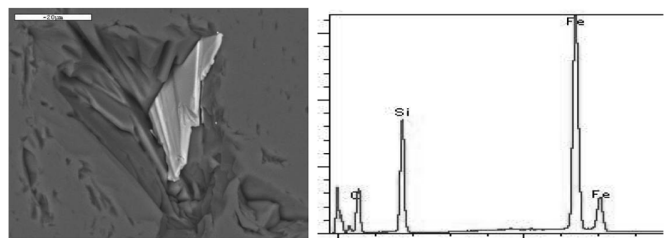

DongGol $b$ (cross section)
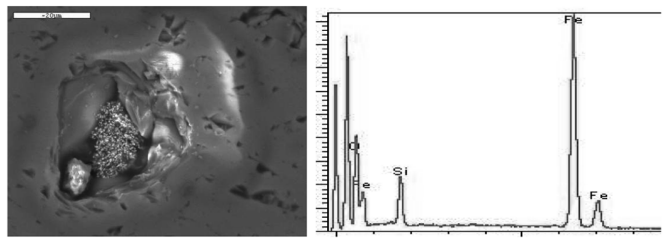

EonYang a (cross section)

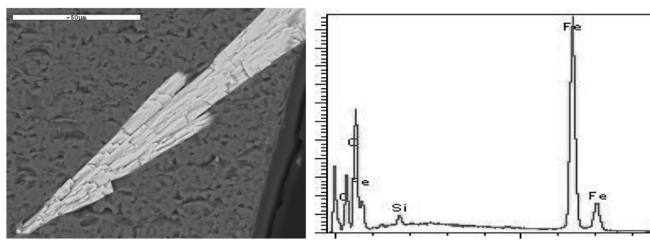

China a(cross section)

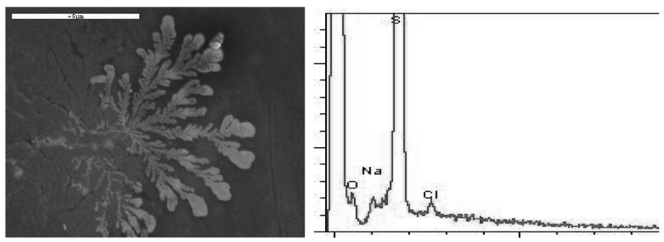

China c(evaporite)

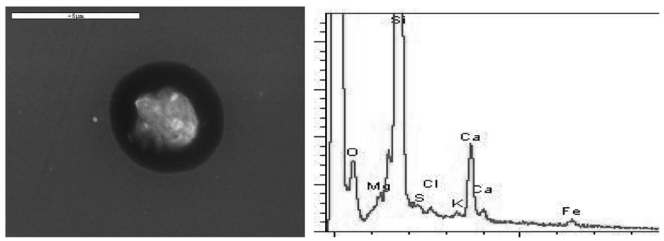

Synthetic b(evaporite)

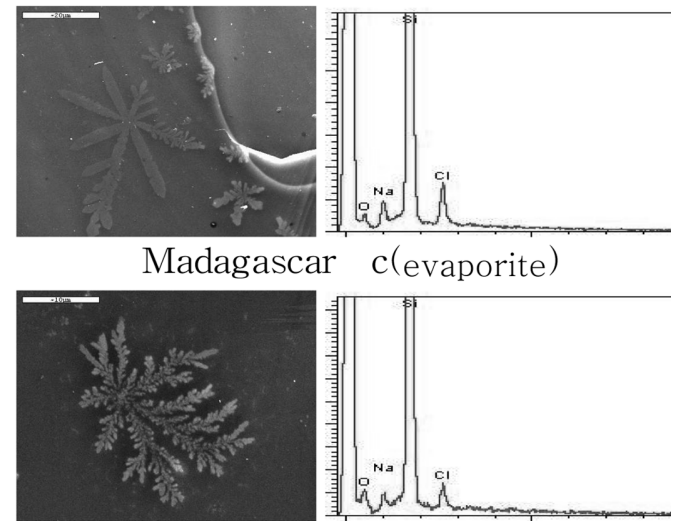

U1Jin b(evaporite)
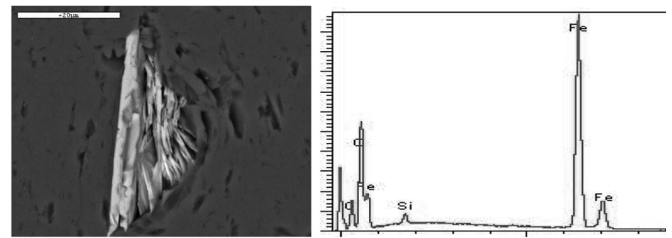

DongGol a(cross section)
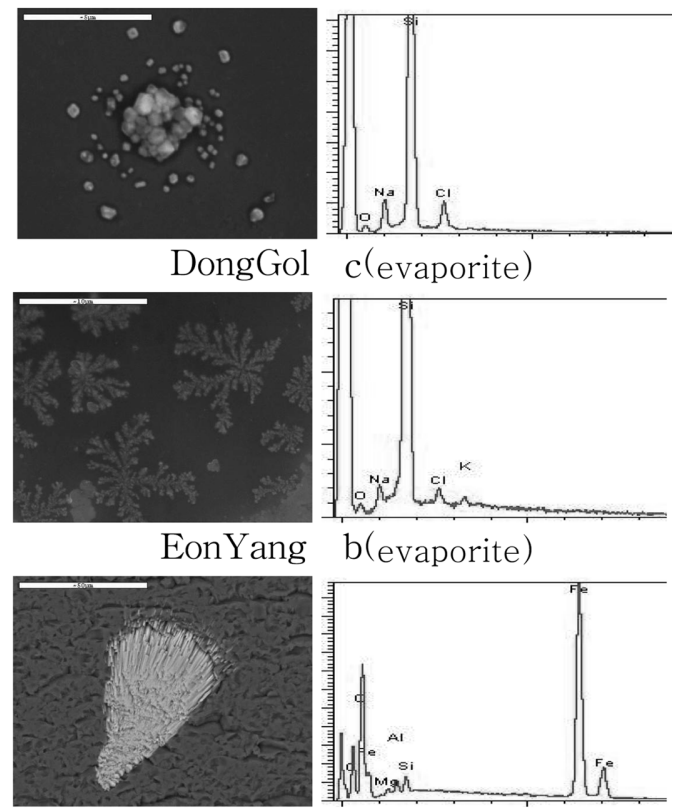

China $b$ (cross section)

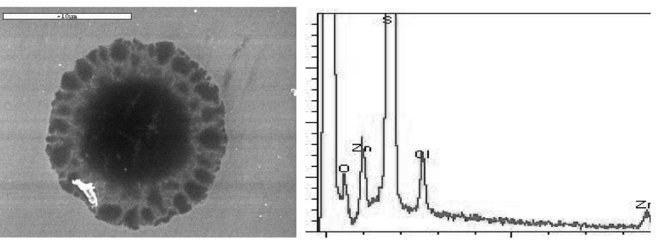

Synthetic a(evaporite)

Fig. 2. Continued. 
$\times 20,000$ 의 배율에서 $\mathrm{SEM} / \mathrm{EDS}$ 분석을 하였다. 관찰용 시료는 내포물이 비교적 많이 관찰되는 자수정 원석시료 를 판상으로 절단하고 연마하여 제작하였다. 따라서 $\mathrm{SEM}$ 이미지에서는 내포물들의 단면이 주로 관찰되었고 $\mathrm{EDS}$ 에서 분석된 성분들은 그 단면의 화학조성이다. 또 한 $\mathrm{SEM} / \mathrm{EDS}$ 관찰을 위한 감압코팅과정에서 자수정에 포획되어 있던 액상포유물이 파괴되고 그 조성물이 시료 표면으로 흘러 나와 증발하면서 생성하는 수지상 무늬 (dendrite) 또는 액적의 형상과 화학조성을 분석함으로써 액상포유물 내 염성분의 조성도 조사하였으며 그 결과를 Fig. 2에 나타내었다.

그림의 결과에서 천연자수정에서는 $\mathrm{Fe}$ 함량이 높은 함 철 내포물과 $\mathrm{Na}$ 와 $\mathrm{K}$ 를 함유하는 dendrite가 관찰되는 공통점이 발견되고 합성자수정에서는 내포물이 거의 관 찰되지 않으나 드물게 $5 \mu \mathrm{m}$ 이하의 극 미세 구형 내포 물들이 관찰되는 특징을 보이며, 각 시료별로 그 특징을 나열하면 다음과 같다.

브라질 자수정에서는 $5 \mu \mathrm{m}$ 정도의 dendrite들이 구형 으로 모여 있는 것(Brazil c)이 관찰되었으며 그 주성분 은 $\mathrm{Na}, \mathrm{K}, \mathrm{Cl}$ 이었고 $\mathrm{K}$ 의 농도가 $\mathrm{Na}$ 의 농도 보다 높은 특징을 보였다. 또한, $\mathrm{Ca}$ 와 $\mathrm{S}$ 를 다량 함유한 벌집모양의 dendrite(Brazil b)도 관찰되었다. 고체내포물(Brazil a)은 크기가 $50 \mu \mathrm{m}$ 정도인 부채꼴의 단면을 보였고 그 주 성분 은 철산화물이었으며 약간의 $\mathrm{Al}, \mathrm{Mg}$ 을 함유하고 있었다.

볼리비아 자수정에서는 브라질 자수정과 매우 유사한 내포물들이 관찰되었다. 즉 $\mathrm{Na}, \mathrm{K}, \mathrm{Cl}$ 을 주성분으로 하 는 dendrite(Bolivia $\mathrm{c}$ )와 $\mathrm{Ca}$ 와 $\mathrm{S}$ 를 다량 함유한 dendrite (Bolivia b)가 관찰되었으며 $5 \mu \mathrm{m}$ 정도의 원형 단면(a)이 관찰되었고 그에 대한 $\mathrm{EDS}$ 도형에서는 $\mathrm{Fe}$ 의 높은 피크 와 함께 $\mathrm{O}, \mathrm{Al}, \mathrm{Si}$ 의 낮은 피크도 관찰되었다. 따라서 이것도 철산화물 계열의 내포물로 판단된다. 다만 볼리 비아 자수정과는 달리 dendrite(Bolivia c)의 조성 중 $\mathrm{Na}$ 의 농도가 오히려 $\mathrm{K}$ 의 농도 보다 높은 특징을 보였다.

우루과이 자수정에서는 브라질 자수정에서 관찰되었던 부채꼴 모양(Uruguay a)의 내포물과 조성과 형상이 매 우 유사한 함철 내포물이 관찰되었고, dendrite(Uruguay $\mathrm{b})$ 의 조성 중 $\mathrm{K}$ 와 $\mathrm{Na}$ 의 함량은 비슷하게 나타났다. $\mathrm{Ca}$ 와 $\mathrm{S}$ 의 피크가 나타나는 액적(液滴)(Uruguay c)은 원형 에 가까운 모양을 하고 있었다.

이상의 결과에서 남미대륙의 자수정들은 모두 내포물 에 $\mathrm{K}, \mathrm{Na}, \mathrm{Cl}$ 을 주성분으로 하는 dendrite와 함께 $\mathrm{Ca}$ 와 $\mathrm{S}$ 성분을 함유하는 액적(液滴)이 관찰되는 공통점을 보였 다. 열수환경의 온도, 압력, 산소분압, 화학조성 등을 고 려할 때 이들 $\mathrm{Ca}$ 와 $\mathrm{S}$ 성분 무수석고 $\left(\mathrm{CaSO}_{4}\right)$ 의 형태로 존재하였을 가능성이 높아 보인다. dendrite의 주 성분인 $\mathrm{K}$ 와 $\mathrm{Na}$ 의 조성비를 비교한 결과 브라질 자수정은 $\mathrm{K}>$ $\mathrm{Na}$ 이고, 볼리비아 자수정은 $\mathrm{K}<\mathrm{Na}$, 우루과이 자수정은
$\mathrm{K}=\mathrm{Na}$ 로 나타났다.

자이레 자수정에서는 dendrite가 나타나지 않았는데 이는 자이레 자수정에는 액상포유물이 매우 작음을 의미 한다. 극히 일부에서 관찰되는 액적(Zaire c)은 $\mathrm{Na}, \mathrm{K}$, $\mathrm{Cl}, \mathrm{S}$ 를 주성분으로 하고 $\mathrm{Ca}$ 를 함유하지 않는 특징을 보였다. 고체포유물은 침상(Zaire a) 또는 판상(Zaire b) 의 모양을 하고 크기는 단경 $1 \sim 15 \mu \mathrm{m}$, 장경 $30 \sim 150 \mu \mathrm{m}$ 정도 이었으며 주성분은 $\mathrm{Fe}$ 이고 $\mathrm{O}$ 의 함유량이 작은 특 징을 보인다.

잠비아 자수정에서는 $\mathrm{Fe}$ 와 $\mathrm{O}$ 를 다량 함유하는 굵은 침상의 함철 내포물 $(Z a m b i a$ a)과 $\mathrm{K}, \mathrm{Na}, \mathrm{Cl}$ 을 주성분으 로 하는 dendrite(Zambia b) 그리고 $\mathrm{Mg}$ 와 $\mathrm{S}$ 로만 구성 된 해파리 모양의 액적(Zambia c)이 관찰되었다.

마다가스카르 자수정에서는 dendrite(Madagascar c) 가 $\mathrm{Na}$ 와 $\mathrm{Cl}$ 만을 주성분으로 하는 특징을 보였으며, 고체포유물이 비교적 많이 관찰되었고 그 형상은 구형 (Madagascar a), 부채꼴(Madagascar b), 아메바모양 등 매우 다양 하였고 주성분은 $\mathrm{Fe}$ 이고 $\mathrm{O}$ 의 함량은 낮은 특 징을 보였다. 특히 (b)의 부채꼴에 대한 $\operatorname{EDS}$ 분석에서 는 브라질과 우루과이의 경우와 매우 유사한 $\mathrm{Fe}$ 의 주 피크와 함께 $\mathrm{Mg}$ 와 $\mathrm{Al}$ 의 작은 피크가 관찰되었다.

울진 자수정에서는 $\mathrm{Fe}$ 와 $\mathrm{O}$ 를 주성분으로 하고 $\mathrm{Al}, \mathrm{P}$, $\mathrm{S}$ 등을 소량 함유하는 부정형의 함철 내포물(Uljin a)이 관찰되었고, dendrite(Uljin b)는 $\mathrm{Na}$ 와 $\mathrm{Cl}$ 만 주성분으로 하는 특징을 보였으며 $\mathrm{Ca}$ 를 함유하지 않는 럭비공 모양 의 액적(Uljin c)이 관찰되었다.

동골 자수정에서는 $\mathrm{Fe}$ 를 주성분으로 하고 $\mathrm{O}$ 의 함량이 작은 반달모양(Donggol a) 또는 판상(Donggol b)의 함 철 내포물들이 주로 관찰되었고, dendrite는 관찰되지 않 았으며 $\mathrm{Na}$ 와 $\mathrm{Cl}$ 을 주성분으로 하는 방사상 액적(Donggol a)들이 관찰되었다.

언양 자수정에서는 $\mathrm{Fe}$ 와 $\mathrm{O}$ 를 주성분으로 하는 타원형 의 함철 내포물과 $\mathrm{Fe}$ 를 주성분으로 하고 $\mathrm{O}$ 를 소량 함유 하는 부정형의 함철 내포물(Eonyang a) 들이 관찰되었 으며, $\mathrm{K}, \mathrm{Na}, \mathrm{Cl}$ 을 주성분으로 하는 dendrite(Eonyang b)가 관찰되었다.

중국 자수정에서는 $\mathrm{Fe}$ 를 주성분으로 하는 화살표 모양 의 내포물(China a), 그리고 브라질, 우루과이, 마다가스 카르산 자수정에서 관찰되었던 것과 조성 및 모양이 매 우 유사한 부채꼴 내포물(China b)이 관찰되었고 $\mathrm{Na}$ 와 $\mathrm{Cl}$ 을 주성분으로 하는 dendrite(China c)가 관찰되었다.

합성 자수정에서는 내포물이 거의 관찰되지 않았으나 드물게 $\mathrm{Zn}$ 을 함유하는 $5 \mu \mathrm{m}$ 이하의 극미세 구형 내포 물(Synthetic a)과 $\mathrm{Ca}$ 함량은 높으나 $\mathrm{Na}$ 를 전혀 포함하지 않는 구형 액적(Synthetic b)들이 관찰되었다.

이상과 같은 $\mathrm{SEM} / \mathrm{EDS}$ 를 이용한 자수정의 내포물 관 찰 결과로부터 $\mathrm{SEM}$ 으로 형상을 관찰하고 $\mathrm{EDS}$ 로 그 화 
학조성을 파악함으로써 자수정의 산지를 감별하기 위한 기초 자료들을 얻을수 있음을 확인하였으며 그 결과를 요약하면 다음과 같다. 즉, 남미대륙의 천연자수정들은 dendrite, 액적, 함철내포물을 모두 함유하는 공통점을 보였으며 그 중에서 브라질산은 dendrite의 조성 중 $\mathrm{K}$ 의 함량이 $\mathrm{Na}$ 의 함량에 비해 매우 높은 특징이 있고, 볼리 비아산은 $\mathrm{Na}$ 함량이 $\mathrm{K}$ 함량 보다 매우 높으며, 우루과이 산은 $\mathrm{K}$ 와 $\mathrm{Na}$ 의 함량이 비슷한 경향을 보였다. 또한, 브 라질산과 우루과이산에서는 $\mathrm{Fe}$ 와 $\mathrm{O}$ 의 함량이 모두 높은 부채꼴의 함철내포물이 관찰되는 반면에 볼리비아산에서 는 $\mathrm{Fe}$ 함량은 높으나 $\mathrm{O}$ 의 함량이 낮은 원형 함철내포물 이 관찰되는 특징을 보였다. 자이레산은 dendrite를 보이 지 않았고 액적 내에 $\mathrm{Ca}$ 이 전혀 함유되어 있지 않으며 $\mathrm{O}$ 를 거의 함유하지 않는 판상 또는 침상의 함철내포물 이 관찰되는 특징을 보였다. 잠비아산의 경우는 dendrite 의 조성 중 $\mathrm{Na}$ 함량이 $\mathrm{K}$ 함량 보다 높고 액적은 $\mathrm{Mg}$ 와 $\mathrm{S}$ 로만 구성되어 있으며, $\mathrm{Fe}$ 와 $\mathrm{O}$ 를 모두 다량 함유하는 침상 함철내포물이 관찰되는 특징을 보였다. 마다가스카 르산은 $\mathrm{Na}$ 와 $\mathrm{Cl}$ 로만 구성된 dendrite를 가지며, 액적이 나타나지 않고, $\mathrm{O}$ 를 포함하지 않는 부채꼴, 구형, 아메 바모양 등 다양한 형상의 함철내포물들이 관찰되는 특징 을 보였다. 우리나라의 울진산은 $\mathrm{Na}$ 와 $\mathrm{Cl}$ 로만 구성된 dendrite를 가지며 액적 내에 $\mathrm{Ca}$ 를 함유하지 않고 $\mathrm{Fe}$ 와 $\mathrm{O}$ 를 다량 함유하는 부정형의 함철 내포물이 관찰되는 특징을 보였다. 동골산은 dendrite가 관찰되지 않고 $\mathrm{Na}$ 와 $\mathrm{Cl}$ 로만 구성된 액적이 관찰되며 $\mathrm{O}$ 를 거의 함유하지 않는 판상 또는 반달 모양의 함철 내포물이 관찰되는 특 징을 보였다. 언양산은 dendrite내에 $\mathrm{K}, \mathrm{Na}, \mathrm{Cl}$ 을 모두 함유하고 액적이 관찰되지 않으며 $\mathrm{O}$ 를 소량 함유하는 부정형의 함철 내포물이 관찰되는 특징을 보였다. 중국 산은 $\mathrm{Na}$ 와 $\mathrm{Cl}$ 로만 구성된 dendrite를 보이고 액적은 나 타나지 않으며 약간의 산소를 포함하는 부채꼴 또는 화 살표 모양의 함철 내포물이 관찰되는 특징을 보였다. 합 성 자수정은 dendrite가 전혀 관찰되지 않았으며 액적내 에서는 $\mathrm{Ca}$ 함량이 높으나 $\mathrm{Na}$ 를 전혀 포함하지 않는 특 징을 가지며 함철 내포물은 전혀 관찰되지 않고 $\mathrm{Zn}$ 을 함유하는 구형의 내포물이 관찰되는 특징을 보였다.

이상의 결과에서 자수정에 포획되어 있던 유체포유물 들은 $\mathrm{SEM} / \mathrm{EDS}$ 분석을 위한 감압코팅과정에서 파괴 되어 시료표면으로 흘러나와 증발되면서 수지상구조인 dendrite 또는 다양한 형태의 액적을 만드는 것을 알 수 있으며, dendrite는 주로 $\mathrm{K}, \mathrm{Na}, \mathrm{Cl}$ 등으로 구성되어있고 액적은 $\mathrm{K}, \mathrm{Na}, \mathrm{Cl}$ 외에도 $\mathrm{Ca}, \mathrm{Mg}, \mathrm{S}$ 등의 다양한 성분 을 함유하고 있음을 알 수 있다. 유체포유물이 dendrite 를 형성할지 액적을 형성할 지는 유체포유물의 화학조성 변화나 염농도, 점도 등도 관여하겠지만 무엇보다도 증 발속도가 가장 중요한 요소로 작용할 것으로 생각된다.
즉, 감압과 함께 염용액이 시료의 표면으로 서서히 흘러 나와 증발될 경우는 흘러나오기 시작한 지점에서부터 서 서히 수지상구조가 발달하고 폭발적으로 터져 나올 경우 는 다양한 형태의 액적을 형성하는 것으로 생각된다.

뿐만아니라, 대부분의 자수정 시료에 포획되어 있는 고체내포물은 철과 산소를 주성분으로 하는 적철석계의 내포물 만이 관찰됨을 알 수 있으며 이는 “아시아 지역 의 자수정에 포획되어 있는 고체 내포물에는 적철석, 칼 륨장석 결정 등의 내포물이 존재한다"는 기존의 연구 결 과 $[7,8]$ 와는 다소 다른 결과이다. 또한 상온에서의 상비 율 관찰 실험에서는 일관성 있는 자료를 얻기가 힘들었 으나 아프리카 대륙의 마다가스카르와 아시아대륙의 자 수정에서는 기상 보다는 액상의 포유물들이 절대적으로 많음이 관찰되었고, 그들의 조성도 비교적 높은 농도의 $\mathrm{K}, \mathrm{Na}, \mathrm{Cl}$ 을 나타내므로 Type III에 속하는 것으로 추정 되어 기존의 연구결과 $\{9,10\}$ 와 일치되는 결과를 얻었다.

\section{3. 자수정의 화학조성과 미량성분의 농도}

$\mathrm{X}$-선 형광분석기(XRF)를 이용하여 시료로 사용된 자 수정들의 주요 구성원소를 분석한 결과 전 시료에서 $\mathrm{SiO}_{2}$ 함유량이 $99 \mathrm{wt} \%$ 이상을 차지하고 있었으며, 자수정의 발색에 가장 큰 영향을 주는 것으로 알려져 있는[11] $\mathrm{Fe}$ 의 함량은 자이레 자수정에서 $0.21 \mathrm{wt} \%$, 언양 자수정이 $0.11 \mathrm{wt} \%$ 로 나타났다. 그러나 이들 농도는 모두 XRF의 정량한계인 $0.1 \%$ 에 가까운 값들이므로 그 신뢰성은 낮 은 편이다. 따라서 보다 정밀한 분석을 위하여 $0.01 \mathrm{ppm}$ 까지 분석 가능한 ICP-AES로 정량 분석을 행하였다.

ICP-AES로 규산염광물을 분석하는 경우에 있어서 가 장 주의하여야 할 점은 화학적 저항성이 큰 $\mathrm{SiO}_{2}$ 내부 에 포획되어 산처리 과정에서 용해되지 않고 잔류하는 성분이 없도록 하는 것이다. 따라서 이 경우 테프론 용 기에 시료를 넣고 플루오르수소산과 황산의 혼산으로 처 리하여 $\mathrm{SiO}_{2}$ 를 $\mathrm{SiF}_{4}$ 의 형태로 기화시켜 완전히 제거하여 야만 한다.

본 연구에서도 상기의 방법으로 $\mathrm{SiO}_{2}$ 를 완전히 제거한 다음 ICP-AES 분석을 행하였으며, 그 결과를 Fig. 3 Fig. 5에 나타내었다. 그림의 결과에서 자수정에 공통적 으로 함유되어 있는 불순 원소로는 $\mathrm{Ca}, \mathrm{Fe}, \mathrm{Mg}, \mathrm{Al}$, $\mathrm{Na}, \mathrm{K}$ 등임을 알 수 있다.

Fig. 3 은 $\mathrm{Ca}, \mathrm{Fe}, \mathrm{Mg}$ 의 농도 분포를 산지별로 나타낸 것으로, $\mathrm{Ca}$ 의 농도는 잠비아 자수정에서 가장 낮은 36.9 $\mathrm{ppm}$ 이고 합성자수정 $\mathrm{A}$ 에서 가장 높은 $175 \mathrm{ppm}$ 을 나타 낸다. $\mathrm{Fe}$ 의 농도는 언양 자수정이 가장 낮은 $21.1 \mathrm{ppm}$ 을, 자이레A 자수정이 가장 높은 $309.2 \mathrm{ppm}$ 을 나타낸다. $\mathrm{Mg}$ 의 농도는 잠비아 자수정이 가장 낮은 $9 \mathrm{ppm}$ 이었고, 합성자수정 $\mathrm{A}$ 가 가장 높은 $43.3 \mathrm{ppm}$ 이었다. 아울러 우루 


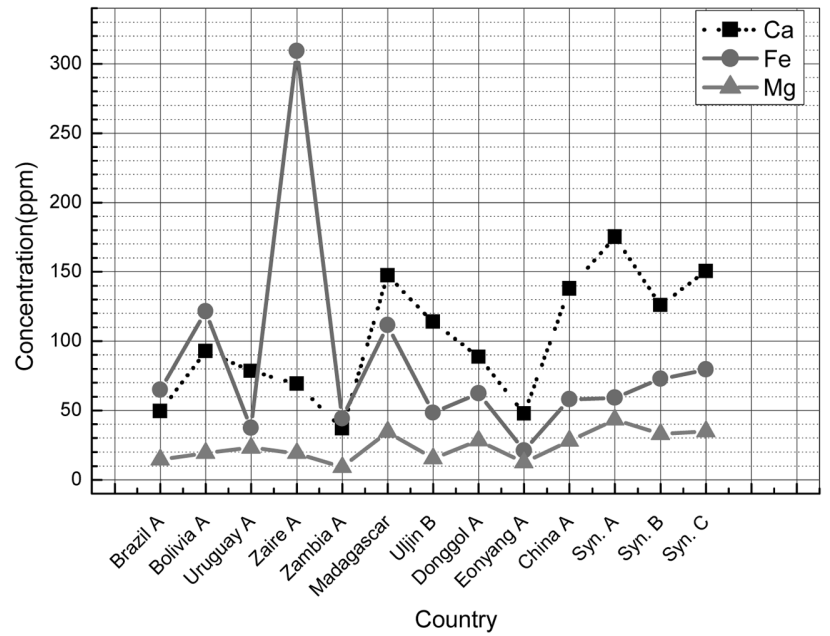

Fig. 3. Concentration of $\mathrm{Ca}, \mathrm{Fe}$ and $\mathrm{Mg}$ contained in amethyst of various origin.

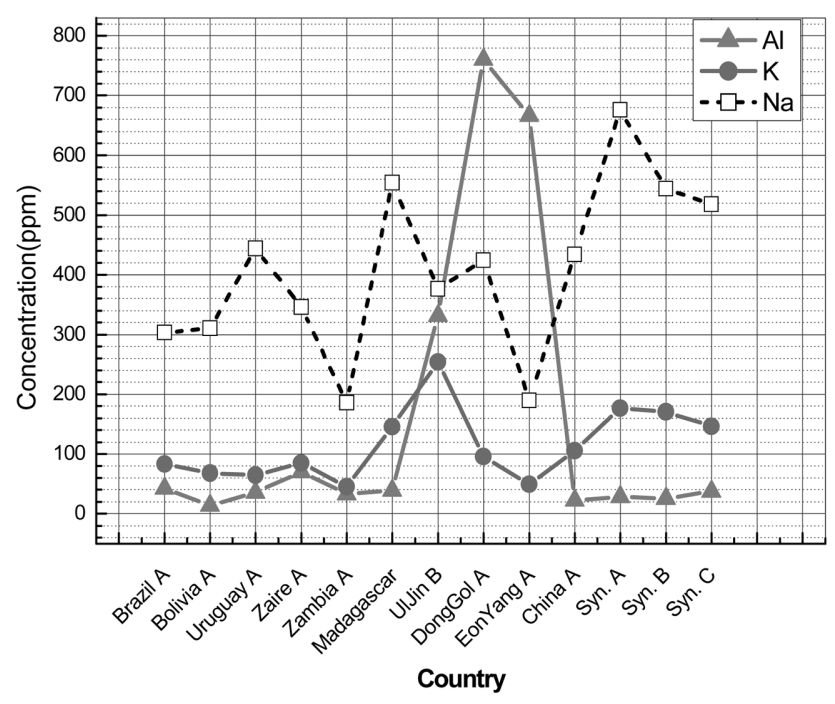

Fig. 4. Concentration of $\mathrm{Al}, \mathrm{Na}$ and $\mathrm{K}$ contained in amethyst of various origin.

과이, 자이레수정(citrine)을 제외한 대부분의 시료에서 $\mathrm{Ca}, \mathrm{Fe}, \mathrm{Mg}$ 의 농도 중 어떤 한 원소의 농도가 높을 경 우 다른 두 원소의 농도도 높아지는 경향이 있음을 알 수 있으며 이는 이들 세 원소사이에는 양의 상관관계가 있음을 의미한다.

Fig. 4는 $\mathrm{Al}, \mathrm{K}, \mathrm{Na}$ 의 농도 분포를 산지별로 나타낸 그림이다. 그림에서 $\mathrm{Al}$ 은 볼리비아가 가장 낮은 $13.5 \mathrm{ppm}$ 이었고 전반적으로 $30 \mathrm{ppm}$ 전후의 농도를 보였으나 한 국산 자수정에서는 331.1 760.6의 매우 높은 농도를 나 타내었다.

$\mathrm{K}$ 는 잠비아 자수정이 가장 낮은 $45.2 \mathrm{ppm}$ 을 나타내었 고 울진B자수정이 가장 높은 $254.3 \mathrm{ppm}$ 을 나타내었으며 합성자수정에서는 $146.4 \sim 177 \mathrm{ppm}$ 의 비교적 균일한 농도 를 보였다.

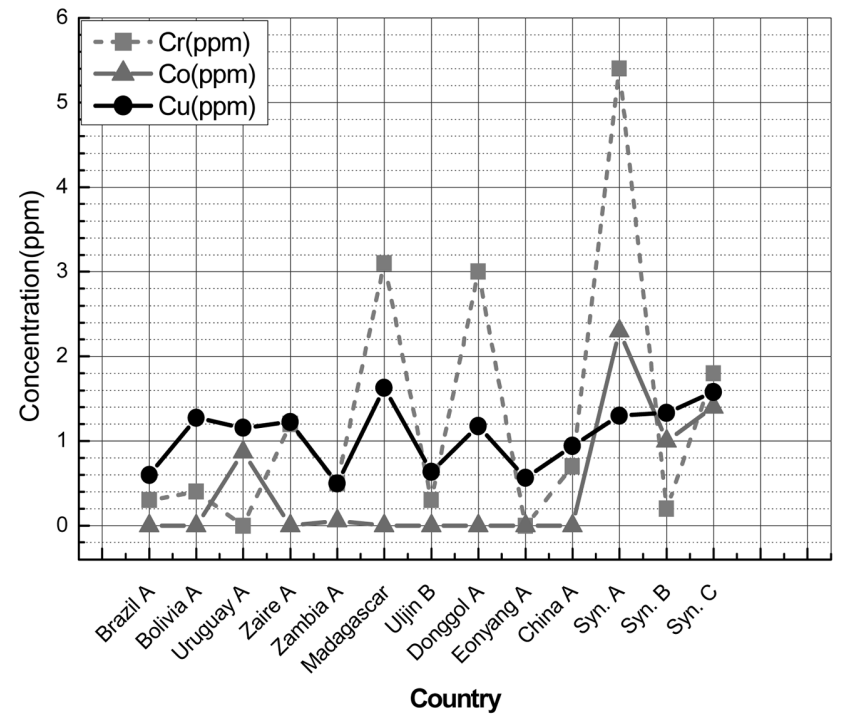

Fig. 5. Concentration of $\mathrm{Cr}, \mathrm{Co}$ and $\mathrm{Cu}$ contained in amethyst of various origin.

$\mathrm{Na}$ 의 농도는 잠비아 $\mathrm{A}$ 가 가장 낮은 $185.7 \mathrm{ppm}$ 을 보였고 합성 $\mathrm{A}$ 가 가장 높은 $676 \mathrm{ppm}$ 을 나타내었다. $\mathrm{Na}$ 와 $\mathrm{K}$ 의 농 도 사이에는 밀접한 상관관계가 있음을 알 수 있었다.

Fig. 5는 비교적 미량으로 함유된 $\mathrm{Cr}, \mathrm{Co}, \mathrm{Cu}$ 의 농도 를 나타낸 그림이다. $\mathrm{Cr}$ 은 마다가스카르, 동골 $\mathrm{A}$, 합성 $\mathrm{A}$ 자수정에서 $3 \sim 5 \mathrm{ppm}$ 이 관찰되었다. 합성 $\mathrm{A}$ 안의 $\mathrm{Cr}$ 함 유는 결정성장용기의 재질이 스테인레스강 이기 때문으 로 생각된다.

$\mathrm{Cu}$ 는 모든 자수정에서 거의 동일한 $1 \mathrm{ppm}$ 정도의 농 도를 보였다. $\mathrm{Co}$ 는 합성자수정에서만 특징적으로 관찰되 었고 농도는 1 2 ppm이었다.

합성자수정이 코발트를 함유하는 것은 착색과정에서 Co-60 감마선을 조사한 영향으로 생각되며, 합성자수정 에 함유된 미량 원소들의 농도가 비교적 균일한 값을 보 이는 것은 자수정 결정의 육성과정에서 그 농도를 엄격 히 조절하고 있기 때문으로 생각된다.

이상의 본 연구에서 진행된 ICP-AES 분석 결과를 종 합하면 합성자수정은 $\mathrm{Co}$ 를 반드시 함유하는 특징을 보 이며, 그 밖에 $\mathrm{K}, \mathrm{Na}, \mathrm{Ca}, \mathrm{Fe}$ 등이 비교적 고농도로 함 유되어 있는 특징을 보였다. 따라서 합성 자수정의 결정 육성 또는 발색을 위하여 $\mathrm{K}, \mathrm{Na}, \mathrm{Ca}, \mathrm{Fe}$ 등을 첨가하는 것으로 생각된다.

한국산 자수정에서 $\mathrm{Al}$ 성분이 높게 나타나는 것은 점 토질의 내포물 때문으로 생각된다.

$\mathrm{Na}$ 의 농도와 $\mathrm{K}$ 의 농도가 양의 상관관계를 보이는 것 은 이들이 대부분 유체 내포물내에 일정한 성분비로 함 께 함유되어 있기 때문에 유체내포물의 다소에 따라 그 농도가 동시에 변하는 것으로 생각된다. 다만, 유체내포 물을 거의 갖지 않는 합성자수정에서도 이러한 현상이 
나타나는 것은 상기한 바와 같이 결정 육성과정에서 그 농도를 엄격하게 조절하여 첨가하기 때문으로 생각된다.

따라서 ICP-AES 분석에 의한 미량원소의 분석으로 합성과 천연의 구분뿐만 아니라 산지 감별에의 응용도 가능함을 알 수 있었다. 이 분석 방법은 파괴적인 방법 이므로 가공된 보석의 감별에는 적용하기가 어렵지만 다 량으로 거래되는 원석의 감별에는 매우 유용할 것으로 생각된다.

\section{4. 결 론}

자수정의 산지에 따른 내포물의 성상 변화를 조사함으 로써 자수정의 산지 감별을 위한 기초자료를 얻을 목적 으로 수행된 본 연구를 통하여 얻어진 결론들을 요약하 면 다음과 같다.

1) 자수정 내포물의 형상과 고체포유물의 화학조성 및 단면의 모양, 그리고 $\mathrm{SEM} / \mathrm{EDS}$ 관찰을 위한 감압코팅과 정에서 자수정에 포획되어 있던 액상포유물이 파괴되어 시료 표면으로 유출되어 증발됨으로써 생성하는 dendrite 또는 액적의 화학조성이 산지에 따라 달라짐을 확인하였 으며 이들 자료로부터 자수정의 산지를 추정하는 것이 가능할 것으로 생각되었다.

2) 합성자수정은 특징적으로 $1 \sim 2 \mathrm{ppm}$ 의 $\mathrm{Co}$ 를 함유하 는 것과 같이 천연자수정에서도 산지에 따라 미량원소의 함량이 서로 다름을 알 수 있었으며 따라서 ICP-AES 분석에 의한 미량원소의 분석으로 합성과 천연의 구분뿐 만 아니라 산지의 감별도 가능함을 알 수 있었다. 이 분 석 방법은 파괴적인 방법이므로 가공된 보석의 감별에는 적용하기가 어렵지만 다량으로 거래되는 원석의 감별에
는 매우 유용할 것으로 생각된다.

\section{참 고 문 헌}

[1] T. Lu and J. E. Shigley, "Optical characterization of synthetic faceted gem materials grown from hydrothermal solution", Procedings of SPIE Reprint 3425 (1998 Jul) 37 .

[2] C. Fenelle, "Synthetic amethyst difficult to detect, infiltrates gem market", National Jeweler 42(17) (1998 Sep) 84.

[3 ] R.C. Kammerling, et al., "Gem News: Unusual colorzoned synthetic amethyst", Gems and Gemology 31(3) (1995) 213.

[4] W.S. Kim, "Gemmological characterization of EonYang Amethyst", International Symposium on natural History and Enviroments (1996) 83.

[5] E. Gubelin and J. Koivula, "Inclusion of gem", Chun Gwang Publishing Co. (1993) 309.

[6] S.M. Kim, "Fluid inclusion study of amethysts deposits and related granites in EonYang", Pusan National University (1994) 8.

[ 7 ] W.S. Kim, H.S. Shin and S.S. Lee "Characterization of Inclusions in Amethysts from EonYang, Korea", Journal of Mineralogical Society of Korea 1(2) (1988) 83.

[8] S.M. Kim, "Fluid inclusion study of amethysts deposits and related granites in EonYang", Pusan National University (1994) 8.

[9] V. Balitsky, T. Lu and G. Rossman, "Russian synthetic ametrine", Gems and Gemology 35(2) (1999) 122.

[10] W.S. Kim, S.S. Lee and K.J. Na, "Growing, mineralogical and gemmological study of synthetic amethyst", J. of Korean Earth Science Society 12(1) (1991) 59.

[11] C.S. Han, "Electron spin resonance spectra of natural amethyst", J. of Soonchunhyang University 7(4) (1984) 417. 